\title{
Germinal Center-Associated Signaling and Motility Protein
}

National Cancer Institute

\section{Source}

National Cancer Institute. Germinal Center-Associated Signaling and Motility Protein. NCI

Thesaurus. Code C126994.

Germinal center-associated signaling and motility protein (178 aa, $\sim 21 \mathrm{kDa}$ ) is encoded by the human GCSAM gene. This protein plays a role in both the negative regulation of lymphocyte motility and the modulation of signaling. 